\title{
ACCESSIBILITY AND ACCEPTABILITY OF THE BMI MODEL AT INSTITUTE OF TEACHER TRAINING AND PEDAGOGY
}

\author{
Z Mawardi Effendi ${ }^{1}$, Hansi Effendi ${ }^{2}$ and Hastria Effendi ${ }^{3}$ \\ ${ }^{1}$ Faculty of Economic, Universitas Negeri Padang, Indonesia; ${ }^{2,3}$ Universitas Negeri Padang, Indonesia
}

\begin{abstract}
This reasearch aimed to analyze the accessibility and acceptability of Blended Mobile Instruction Model (BMIM) at Universitas Negeri Padang. The BMIM model is a kind of blended learning model which mix face-to-face learning in the classroom with online learning which uses mobile devices such as mobile phones and tablets. This article based on the result of the first of step of the research and development (R \& D) which used Borg and Gall prosedures. The accessibility of BMIM was studied from three aspects: (1) ownership of mobile devices by lecturers, (2) ownership of mobile devices by students, and 3) the availability of online facilities owned by universities. While the acceptability of the model was measured by using the perception scale which is consisted of four components: (1) the knowledge, (2) the practical value, (3) the interest value, and (4) the difficulties of lecturers and students about BMIM. This research was conducted by using survey method with 100 respondens. This research found out that accessibility and acceptability of BMIM are very good. So the possibility of using BMIM as one of the alternative learning model at UNP in the future is very possible.
\end{abstract}

Keywords: Accessibility, Acceptability, BMI Model, Institute of Teacher Training and Pedagogy

\section{INTRODUCTION}

Try asking students and even lecturers encountered on campus about whether they have a hand phone or tablet. Almost all of them answered yes, and many of them had more than one. Then observe what they are doing when sitting anywhere on campus, almost all of them are using their hand phones or tablets. Even in class attending a lecturer there are still trying to use this communication tool.

Students born in the early 1990s could be called the digital generation. Marc Prensky calls them digital natives, the people born and grown in the age of digital technology [1]. They have been introduced early to digital devices and most of them can use the devises. Do not be suprised to see children who are only about 3-4 years old can already use a computer keyboard to browse the internet, they can easily use the phone to call their mother or father who is outside the house.

The development of digital technology is truly remarkable. It affects almost all aspects of people's lives. Almost all information can be managed and developed by utilizing digital technology, as well as in education. In college, new admissions, academic administration, learning execution, and learning assesment systems are already using digital technology. In accordance with its development, from time to time, it always experience improvement and refinement. Many people think the use of digital technology in the management of a universities is a necessity.

Characteristics of learners is one important factor that is always considered in the design of an effective learning system. The characters of people called digital natives are different from the previous generation called digital immigrant. Some characteristics of digital natives that need to be addressed in the proces of instruction are as follow: They (a) likes freedom, (b) have short attention span, (c) like to express themselves, (d) think fast but loses depth, (e) do not learning from instruction but from searching, (f) have download and upload skills, (g) have interaction habits in social media, and (h) share and collaboration [1].

In 2012, the Government of the Republic of Indonesia enacted Law no. 12 Year 2012 on Higher Education [2]. The Seventh section of this law regulates distance education. Article 4 of this law states that distance education is a model of teaching and learning process conducted through the use of various communication media that can be held on the scope of study program or course.

Furthermore Article 31 paragraph two states distance education aims:

a. to provide Higher Education services to community groups who can not attend face to face or regular education; and

b. to expand access and facilitate higher education services in teaching and learning processs.

The existence of the seventh section of the law on higher education governing distance education is predicted to be linked to the wish of the government to improve access or participation index of higher education which is still low. In 2019 the partisipation index (PI) of Indonesian higher education is expected to reach $32.56 \%$ [3]. This is much lower than the higher education PI in some Asean countries five years ago, for example Malaysia has exceeded $48 \%$. Therefore, to increase in the PI of higher education is one of the most important programs.

Instructional models for universities that utilize 
digital technology continue to emerge. Many universities are beginning to develop online learning or often called e-learning seriously. However, the utilization of e-learning facilities is still very limited in terms of both quantity and quality. Research conducted by researchers in 2015 shows that the last three semesters data shows only about $9 \%$ of the courses offered at UNP utilize e-learning [4]. In addition, this developement of e-learning has not utilized the existing learning management system (Moodle) to its full potential, has not considered student characteristics, and has not been developed based on learning and instruction theory well.

Blended mobile instructional is a learning that utilizes technology and mobile devices. In this case, these devices can be PDAs, cell phones, laptops, tablet PCs, and so on. With mobile learning, users can access learning content anywhere and anytime, without having to visit a particular place at any given time. Thus, users can access educational content without being tied to space and time.

Clark Quinn defines blended mobile instruction as: "The intersection of mobile computing and elearning: accessible resources wherever you are, strong search capabilities, rich interaction, powerful support for effective learning, and performance-based assessment [5]. O'Malley et al. say that blended mobile instruction is "... any sort of learning that happens when the learner is not fixed, predetermined location, or learning that happens when the learner takes advantage of the opportunities offered by mobile technologies" [6].

The purpose of blended mobile instruction development itself is the learning process all the time (long life learning), students can be more active in the learning process, saving time because if applied in the learning process then the student does not necessarily have to attend the class just to collect the task, sent through applications on mobile phones that will indirectly improve the quality of the learning process.

Blended mobile instruction is a learning model that is conducted between places or environments using technology that is easy to carry when the learner is in mobile condition. With its various potentials and advantages, blended mobile instruction is expected to be an alternative learning resource that can improve the efficiency and effectiveness of the process and learning outcomes of future students in Indonesia.

Blended mobile instruction also facilitates the interaction between learners with subject matter. Likewise, the interaction between learners with educators / instructors and among fellow learners can share information or opinions about the sharing of things that concern the lesson or the needs of selfdevelopment learners. Educators / instructors can place the learning materials and tasks that the learners have to do in a particular place in the websites for the learners to access. In accordance with the needs, educators / instructors can also provide opportunities for learners to access certain learning materials and exam questions that can only be accessed by learners only once and within a certain timeframe as well.

\section{RESEARCH METHODOLOGY}

This article is the result of the first step of research and development ( R \& D) that uses the Borg and Gall procedure [7]. The aspects which were studied in this step involve accessibility and acceptability of blended mobile instruction.

Accessibility aspects include ownership of mobile devices, fees provided for the internet connection, and availability of network facilities owned by the University, as well as experience using mobile devices for learning. Data on accessibility is collected by a questionnaire of accessibility consisting of twelve questions with alternative 'yes' and 'no' answers. Since the data are factual, the validity and reliability of the questionnaire are not tested.

Acceptability of blended mobile was measured by perception scale of students and lecturers about blended mobile instruction which covers four aspects: (a) knowledge, (b) practical value, (c) emotional value, and (d) difficulty.

Data acceptability was collected by questionnaire in scale form with possible answers: "strongly agree", "agree", "disagree", and "strongly disagree". The contents validity of this instrument was guaranteed through a questionnaire grid. The item validity of the questionnaire was tested by using the Pearson correlation technique, and the results the twenty items were valid. To ensure the internal reliability of this instrument was used alpha Cronbach test which yielded alpha coefficient of 0.905 .

Data were collected from 50 students and 50 lecturers in clusters from three classes in three faculties, each one class from the Faculty of Economics, Faculty of Sport Sciences, and the Faculty of Engineering.

Data were analyzed with descriptive statistic which consist of mean, standard deviation, graph, and average comparison.

\section{RESULTS AND DISCUSSIONS}

\subsection{Results}

From the point of accessibility, it can be said that the implementation of blended mobile instruction can be accessed easily. This was demonstrated by all of the students and lecturers being sampled had at least a mobile device that can access all types of messages (text, images, audio, and video), can be used in a blended mobile learning environment. All students and lecturers admit that they always use their mobile device to access messages like this. In addition, all students and lecturers claim to provide some money to buy Internet packages. Average amount of money provided by lecturers was more than provided by students as visualized through Fig 1. 


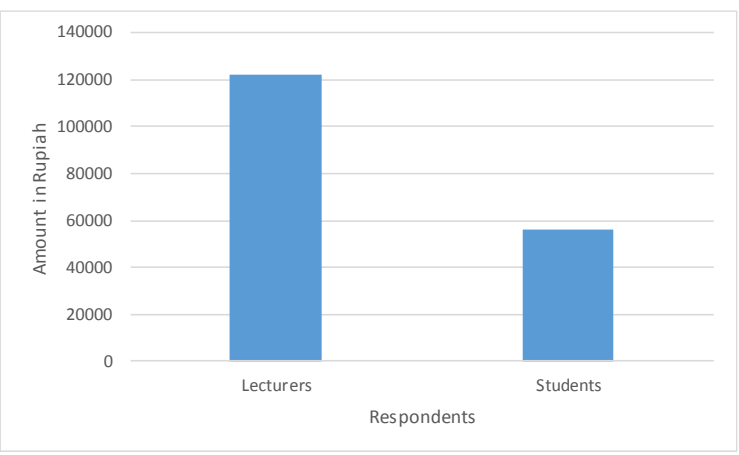

Fig. 1 The comparison of internet budget per month between lecturers and students

Judging from the availability of facilities and the quality of the network owned by the University, all students and lecturers believe that the university has a learning facility that can be used for blended mobile instruction with good quality. This is supported by the fact that University currently has servers with large capacity and with bandwidth greater than $1 \mathrm{Gbps}$ which can be accessed through the internet network.

Furthermore, regarding the acceptability of blended mobile instruction from four aspects covering respondents' a) knowledge, (b) practical value, (c) emotional value, and (d) difficulties about blended mobile instruction, the results could be presented as follows. The mean of lecturer and student score for the four indicators of acceptability of blended mobile instruction presented in Table 1.

Table 1 The mean of lecturer and student score for acceptability of blended mobile instruction

\begin{tabular}{cccccc}
\hline Respondents & N & K & PV & EV & D \\
\hline Lecturers & 50 & 4.27 & 4.04 & 3.86 & 4.04 \\
Students & 50 & 3.94 & 3.86 & 3.59 & 3.52 \\
\hline
\end{tabular}

Note: $\mathrm{K}=$ knowledge; $\mathrm{PV}=$ Practical Value; EV = Emotional Value; $\mathrm{D}=$ Difficulties.

Lecturer scores for the four indicators of acceptability blended mobile instruction were higher than the student score (Fig 2). This may mean that lecturers have a higher acceptability level for blended mobile instruction models than students.

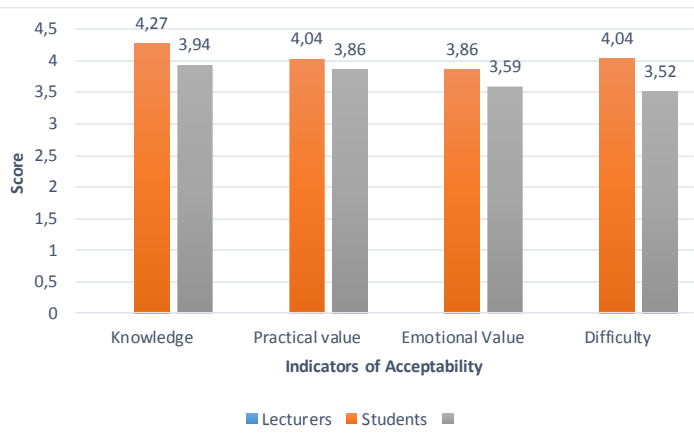

Fig. 2 Lecturers-Student Acceptability of BMI

If the analysis continued with the significance of difference between the lecturers and the students score, this research found out that the score of the knowledge and the difficulty of blended mobile instruction between lecturers and students were significantly different with the F value were 7, 60 and 10.29 respectively.

\subsection{Discussions}

The implementation of Blended Mobile Instruction is expected to be well implemented at the Institute of Teacher Training and Paedagogy when it meets at least two key requirements namely accessibility and acceptability. Basically blended mobile instruction has a very wide capacity to provide services to learners in higher education.

For the state of Indonesia, blended mobile instruction is one of the most promising learning model to increase the participation rate as well as higher education equity which is still a problem.

Just imagine for 2019 Kemenristekdikti makes target for participation index (PI) in higher education of Indonesia about 33\%. This is far below the higher education PI of ASEAN countries five years ago. Traditional Higher Education System by relying on the whole process of learning in the classroom proved less able to increase the PI of higher education Indonesia. This is primarily due to the lack of resources to run these traditional system.

Now with the advancement of information and communication technology and supported by the law the opportunity to increase access and equity of higher education is wide open.

Indeed, according to applicable law a university can not use $100 \%$ e-learning. But by combining faceto-face learning with online learning with a portion of 50: 50, doubled the number of students, a very significant increase.

Now with the number of students as much as approximately 5 million people it is only about $29 \%$ of the population who be 19-24 years old who can participate in higher education. If using a blended mobile instruction acording to the low, the number of students can be raised to 10 million people. It means the PI of higher education reach almost $60 \%$, a very significant improvement.

Of course, building a new model of learning on a large scale is certainly not an easy thing. But now the technology is at hand. The rules that protect it also exist. Its up to our willingness to dare to carry it out. Why it is impossible with more than a hundred public higher education institutions and many outstanding private universities, Indonesia is incapable to implement it.

\section{CONCLUSION}

From the point of accessibility, it can be said that the implementation of blended mobile instruction can be accessed easily. From the survey it was found out 
that accessibility is whether viewed from the tools owned by the students, the facilities owned by the university, and the ability of the lecturer to develop the mobile-based learning is adequate.

Judging from the availability of facilities and the quality of the network owned by the University, all students and lecturers believe that the university has a learning facility that can be used for blended mobile instruction with good quality.

Regarding the acceptability of blended mobile instruction from four aspects, lecturers have a higher acceptability level for blended mobile instruction models than students.

\section{ACKNOWLEDGEMENTS}

This study would not be conducted well and effective without the supports of several parties. The author will deliver gratefulness to:

a. The Rector of UNP, the Deans of Faculty of Economy, Faculty of Engineering, and Faculty of Sport Science who had given supports to make the authors be able to conduct research at computer center, faculties and study programs.

b. The heads of Economic Study Program, Electrical-Engineering Study Program and Health and Recreation Study Program who had given permission to have their lecturers and students to be the respondents of the study.

c. The lecturers and students who willingly provided any information by completing the questionnaires properly.

\section{REFERENCES}

[1] M. Prensky, "Digital Natives, Digital Immigrants Part 1," Horiz., vol. 9, no. 5, pp. 16, 2001 .

[2] Undang-Undang Republik Indonesia No.12 Tahun 2012 tentang Pendidikan Tinggi. Jakarta: Pemerintah Republik Indonesia, 2012.

[3] Peraturan Menteri Riset, Teknologi, dan Pendidikan Tinggi Republik Indonesia No. 13 Tahun 2015 tentang Rencana Strategis Kementerian Riset, Teknologi, dan Pendidikan Tinggi Tahun 2015 - 2019. Kemenristekdikti, 2015.

[4] Z. Mawardi Effendi, H. Effendi, and H. Effendi, "The role of locus control and learning styles in the development of the blended learning model at PSU," Int. J. GEOMATE, vol. 13, no. 7, pp. 75-80, 2017.

[5] C. Quinn, "mLearning. Mobile, Wireless, InYour-Pocket Learning," Linezine, 2000.

[6] C. O’Malley et al., "Guidelines for learning / teaching / tutoring in a mobile environment," Public Deliv. From MOBILearn Proj., 2005.

[7] M. D. Gall, J. P. Gall, and W. R. Borg, "Educational Research: An Introduction," Educational Research: An introduction. Pearson Education Inc., Boston, 2003. 